\title{
DEVELOPMENT AND CHARACTERIZATION OF METAL-DOPANT-BASED ZIRCONIA NANOFIBRES VIA AN ELECTROSPINNING PROCESS FOR SCIENTIFIC APPLICATIONS
}

\author{
RAZVOJ IN KARAKTERIZACIJA KOVINSKIH DOPANTOV NA \\ OSNOVI NANOVLAKEN CIRKONIJEVEGA OKSIDA PREKO \\ ELEKTROSPINING POSTOPKA ZA ZNANSTVENO UPORABO
}

\author{
Mary Jeeva Thomas, John Judes \\ Department of Physics, University VOC College of Engineering, Anna University: Thoothukudi Campus, Thoothukudi - 628008, \\ Tamil Nadu, India \\ maryjeevat@gmail.com
}

Prejem rokopisa - received: 2018-01-29; sprejem za objavo - accepted for publication: 2018-06-28

doi:10.17222/mit.2018.013

Nanofibres and their composites are some of the emerging materials used in versatile applications due to their better compatible performance. Zirconia nanofibres are examples of such materials. Though zirconia nanofibres have better performance, their conductivity is inferior and to boost their performance, doping with metals is required. Thus, the present study deals with the development of zirconia nanofibres doped with copper and iron in different concentrations and hybrid combinations using the electrospinning method with polyvinyl alcohol as a precursor. The developed materials are subjected to a thermal treatment to develop the properties. Both the thermally treated and untreated fibres were characterized using thermogravimetric analysis, Fourier-transform infrared spectroscopy, X-Ray diffraction, scanning electron microscopy coupled with energy-dispersive analysis, viscosity and conductivity measurements. It was concluded that doping thermally treated zirconia nanofibres with a hybrid combination of copper and iron was beneficial.

Keywords: nanofibres, zirconia, copper, iron, calcination, polyvinyl alcohol

Nanovlakna in njihovi kompoziti so obetavni moderni materiali, ki se uporabljajo v različnih aplikacijah zaradi svojih primerjalnih prednosti; nanovlakna cirkonijevega oksida so ena izmed njih. Ceprav imajo cirkonijeva nanovlakna dobre lastnosti, je njihova naravna prevodnost pomanjkljivost, ki jo lahko izboljšamo z legiranjem (dopiranjem) s kovinami. Tako se pričujoča študija ukvarja z razvojem cirkonijevih nanovlaken, ki so legirana (dopirana) $\mathrm{z}$ bakrom in železom v različnih koncentracijah in hibridnih kombinacijah. Pri tem so za izdelavo vlaken uporabljali elektrospining postopek in polivinil alkohol kot prekurzor (izhodišče). Razvite materiale so potem termično obdelali in s tem razvili njihove lastnosti. Tako termično obdelana kot neobdelana vlakna so okarakterizirali s termogravimetrično analizo (TGA; angl.: Thermo Gravimetric Analyser), Fourierjevo transformacijsko Infrardečo kromatografijo (FTIR chromatography), rentgensko difrakcijo, vrstično elektronsko mikroskopijo (SEM) z energijsko disperzijsko spektroskopijo (EDS), meritvami viskoznosti in prevodnosti. Avtorji študije ugotavljajo, da ima dopiranje s hibridno kombinacijo bakra in železa ugoden vpliv na termično obdelana nanovlakna cirkonijevega oksida.

Ključne besede: nanovlakna, cirkonijev oksid, baker, železo, kalcinacija, polivinil alkohol

\section{INTRODUCTION}

Nanofibres are some of the best choices due to their important advantages, resulting from their nano-level diameter with better properties. They are widely used in the field of engineering, health sciences and environmental aspects. Some of the applications include tissue engineering, drug delivery, sensors, etc. ${ }^{1}$ Achieving the nanometre range depends on the various conditions and methods for producing the fibres. The nanofibres are produced by different methods, namely, thermal induced phase separation, drawing, electrospinning and selfassembly synthesis. ${ }^{2}$ Electrospinning is considered as one of the better synthesis methods due to its versatility, inexpensive fabrication, simple construction and ability to be used for various polymers. ${ }^{3,4}$ Ceramic-based nanofibres possess good mechanical strength, thermal strength, electrical and thermal insulation. In particular, zirconia-based nanofibres possess this quality. To in- crease their application suitability and to enhance their conductive nature, it is mandatory to include dopants in the fibre. Zirconium is a transition metal with very good properties that is used in a variety of applications, such as high-temperature applications, corrosion resistant materials, dental implants, knee replacements, prosthetic applications and lotions for poison ivy., Zirconia is blended with the precursor matrix and then made into fibres. Jing et al. developed ultrathin $\mathrm{ZrO}_{2}$ nanofibres using PVP as a precursor by the electrospinning process and proved that calcinated nanofibres have a crystalline phase and it could be used for fibre template applications. $^{7}$ To improve the application range of the zirconia fibres doping was introduced. Zirconia nanofibres doped with erbium was prepared using a modified chemical vapour deposition technique in combination with solution doping to incorporate the glass modifiers and a nucleating agent. Then it was annealed and drawn into the fibres before all the characterisations. It was 
found to possess the ability for multi-wavelength generation and was suitable for the production of compact lasers. ${ }^{8}$ Poly(vinyl) alcohol/zirconium-yttrium acetate (PVA/Zr-Y) nanofibers were prepared with and without boron doping using the electrospinning method. It was proved that boron-doped nanofibres increased the conductivity and produced needle-shaped nanofibres. ${ }^{9}$ It is very clear from the literature that doping enhances the properties like conductivity, diameter, stability, etc. However, there is no research work related to the development of metal-dopants-based zirconia nanofibres with different concentrations and hybridisation. So, the present study deals with the development of zirconia nanofibres with metal dopants of different concentrations, hybridisation, and then calcination of the developed fibres and a comparison with undoped, uncalcinated fibres.

\section{MATERIALS AND METHODS}

\subsection{Materials}

Granular polyvinyl alcohol (PVA, average molecular weight $72,000 \mathrm{~g} / \mathrm{mol}$ ) diluted in distilled water was used as a precursor. Zirconium oxychloride with sodium hydroxide was used to make the zirconia fibres. Copper sulphate ( $\mathrm{Cu}$ dopant), ferric chloride (Fe dopant), and sodium borohydride were used for the preparation of the copper- and iron-based nanofibres. All the above materials, possessing the highest purity, were procured from Sigma Aldrich Suppliers and used as received from the supplier.
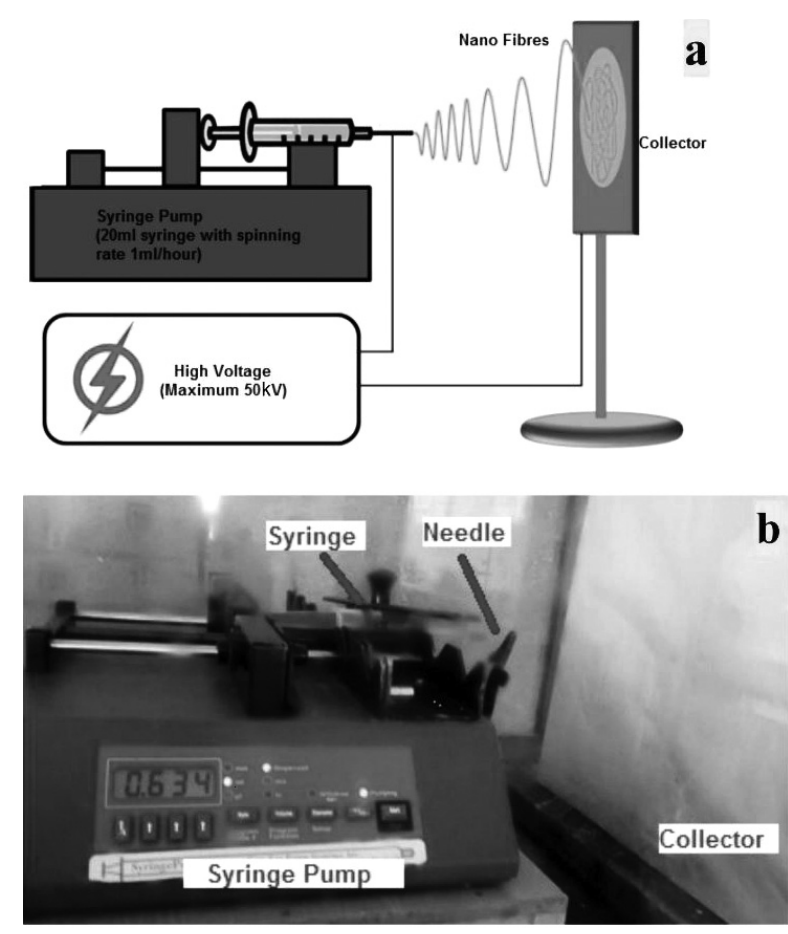

Figure 1: Electrospinning apparatus: a) schematic view and b) photograph

\subsection{Equipment used for the synthesis}

A magnetic stirrer with a hot plate (capable of a maximum operating temperature of $100{ }^{\circ} \mathrm{C}$ ) was used for stirring the solution. An electrospinning machine was used for producing the nanofibres. The electrospinning apparatus possesses a syringe pump with a maximum capacity of $20 \mathrm{~mL}$. The spinning parameters considered in this study were $1 \mathrm{~mL} / \mathrm{h}$ for the dispending rate with a spinning rate of $0.02 \mathrm{~mL}$. The collector was covered with aluminium foil. A voltage is supplied to the syringe and the collector. The anode [positive $(+)$ ] voltage was applied to the syringe needle, and the cathode [negative $(-)$ ] voltage was applied to the back side of the collector (aluminium foil). At the anode, the high voltage applied was $20 \mathrm{kV}$, with the equipment that was capable of producing a voltage of $50 \mathrm{kV}$. After spinning of the total solution, the fibres were peeled off from the aluminium foil. The distance between the syringe and the collector was $13 \mathrm{~cm}$. A schematic representation and a photograph of the electrospinning apparatus are shown in Figure 1.

\subsection{Procedure for the preparation of the sol and development of the fibres}

The PVA solution was prepared by dissolving granular PVA in $100 \mathrm{~mL}$ of distilled water and then stirred using a magnetic stirrer at $70{ }^{\circ} \mathrm{C}$ for two hours to obtain $8 \%$ of the PVA solution. In order to obtain undoped zirconia fibres, zirconium oxychloride of $8 \%$ was dissolved in $100 \mathrm{~mL}$ of distilled water and stirred using a magnetic stirrer. The $8 \%$ sodium hydroxide was dissolved in $100 \mathrm{~mL}$ of distilled water, stirred and titrated with the zirconium oxychloride solution. Then the solution was added drop by drop to the PVA solution at room temperature. Finally, it was stirred for two hours continuously to obtain the homogenous hybrid polymer solution.

Dopant-based zirconia fibres were obtained by following the procedure given below. In order to make $8 \%$ of copper-dopant-based zirconia nanofibres, $8 \%$ of copper sulphate was dissolved in $100 \mathrm{~mL}$ of distilled water using a magnetic stirrer. Then the $8 \%$ of sodium borohydride was dissolved in $100 \mathrm{~mL}$ of distilled water, stirred and titrated against the copper sulphate solution. Upon vigorous stirring, the copper nanoparticle solution was formed. After that the solution was titrated against the zirconia oxychloride-PVA solution. Finally, $8 \%$ copper-doped zirconia-PVA solution was formed by stirring it for two hours at room temperature. Then, the prepared solution was loaded into a syringe pump and spun based on the conditions provided in the above sections. In the case of the $8 \%$ iron-doped solution, instead of titrating against copper sulphate, ferric chloride was used. The other procedures remained the same.

The hybrid dopant-based zirconia nanofibres were formed by following the above procedure with $4 \%$ each of copper sulphate and ferric chloride mixed with 
sodium borohydride. The various $\%$ concentration solutions were prepared by varying the respective chemical solution (e.g., for $6 \%$ copper-doped zirconia nanofibres, $6 \%$ copper sulphate was considered, titrated and spinned, similarly, for the iron-doped zirconia nanofibres, ferric chloride was considered).

To make heat-treated/calcinated nanofibres, the obtained nanofibres were calcinated at $500{ }^{\circ} \mathrm{C}$ for $1 \mathrm{~h}$ in a muffle furnace. The $10 \%$ iron-doped zirconia nanofibres were not developed in this current study due to the viscous nature of the solution that leads to problems in the development of fibres. Based on the above procedure, 16 nanofibres were made (eight calcinated fibres and eight uncalcinated fibres) and were designated as U1 to U8 and $\mathrm{C} 1$ to $\mathrm{C} 8$, as shown in Table 1 . In order to check the calcinated nature of the PVA fibres, it was heat treated at $150{ }^{\circ} \mathrm{C}$ for half an hour only, since prolonged calcination and high temperature will lead to melting of the PVA. The PVA will be removed from the $\mathrm{C} 2$ to $\mathrm{C} 8$ fibres upon calcination at $500{ }^{\circ} \mathrm{C}$.

Table 1: Designation and developed nanofibre details

\begin{tabular}{|l|c|c|}
\hline Developed Sample Details & Uncalcinated & Calcinated \\
\hline PVA & U1 & C1 \\
\hline PVA-Zr & U2 & C2 \\
\hline PVA-Zr-Cu (6\%) & U3 & C3 \\
\hline PVA-Zr-Cu (8\%) & U4 & C4 \\
\hline PVA-Zr-Cu (10\%) & U5 & C5 \\
\hline PVA-Zr-Fe (6\%) & U6 & C6 \\
\hline PVA-Zr-Fe (8\%) & U7 & C7 \\
\hline PVA-Zr-Cu (4\%)-Fe (4\%) & U8 & C8 \\
\hline
\end{tabular}

\subsection{Characterization of the developed nanofibres}

The conductivity and viscosity of the developed solution were measured using a conductivity meter with built-in standard conductance and a A\&D SV-10 viscometer, the standard allowable error is $5 \%$ as per industrial practice. Fourier-transform infrared spectroscopy (FTIR) was used to obtain the information about the absorption/emission by studying the stretching nature of the samples (PerkinElmer, Spectrum-2). FTIR spectra were acquired in the range of $4000 \mathrm{~cm}^{-1}$ to $500 \mathrm{~cm}^{-1}$ with ten scans. A sample of weight $5 \mathrm{mg}$ was used for each measurement. The thermal stability of the developed nanofibres was measured using a thermo gravimetric analyser (TGA) (TGA 50, Shimadzu, Japan). The test conditions were a nitrogen environment, possessing a gas flow rate of $20 \mathrm{~mL} / \mathrm{min}$ with the temperature ranging from room temperature to $800{ }^{\circ} \mathrm{C}$. The heating rate considered was $5{ }^{\circ} \mathrm{C} / \mathrm{min}$, the sample weight considered was $5 \mathrm{mg}$ and a platinum pan was used. An X-Ray diffractometer (XRD) was used to find the crystal structure of the developed nanofibres (Rigaku Ultima III XRD). Scanning electron microscopy (SEM) coupled with energy-dispersive analysis (EDX) was used to study the fibre diameter morphology and the composition (Tescan VEGA 3LMU SEM of Czech Republic). The morphological analysis of the fibres was made using Image $\mathbf{J}$ software.

\section{RESULTS AND DISCUSSION}

The various characterisations carried out are reported and discussed in the following sections in a detailed manner.

\subsection{Physical Properties}

The viscosity of the solution plays an important role in determining the diameter of the spun nanofibres. The results show that an increase in the conductive dopants' concentration increased the viscosity level. For instance, the viscosity of PVA- $\mathrm{Zr}-\mathrm{Cu}(8 \%)$ is 2.89 , while it is 3.13 for PVA-Zr-Cu $(10 \%)$. This increase in viscosity will lead to an increase in diameter. It is also a postulate that a drastic increase in viscosity will have a significant effect on the jet breakup during spinning, leading to small droplets and beads during the electrospinning, as shown in the U5 and U2 composites. These are as per the findings of Tahira Pirzada et al., 2012, ${ }^{10}$ in their study of hybrid silica-PVA nanofibres processed via electrospinning. The optimal percentage of viscosity could overcome this. Adding dopants increased the viscosity, and similar behaviour is seen in the current study, as shown in Table 2.

Conductivity is another important aspect of the electrospinning process. Viscosity and conductance are interdependent in many cases. The higher the viscosity the higher will be the conductance. This postulate was true for all the dopant-based composites in which higher viscosity enhanced the conductance, since the gap between the materials is reduced. Another point noted is the higher the viscosity in case of sample 2, the poorer the conductance. Thus, it is clear that conductance is purely dependent on the conductive nature of the constituent ingredients, as shown in Table 2. It is also worth noting that the higher the conductance, the lower will be the diameter, as per the findings of Seeram et al., ${ }^{11}$ but in the current study it is the opposite. The metal dopants present with the fibres excite the electrons and increase the diameter. Similar behaviour was visualised by Selda Keskin et al., ${ }^{12}$ in their study on neodymium-doped PVA/Zr-Ce oxide nanocrystalline composites.

Table 2: Viscosity and conductivity of the samples

\begin{tabular}{|c|l|c|c|}
\hline $\begin{array}{c}\text { Sample } \\
\text { no }\end{array}$ & \multicolumn{1}{|c|}{ Composite } & $\begin{array}{c}\text { Conducti- } \\
\text { vity (S/m) }\end{array}$ & $\begin{array}{c}\text { Viscosity } \\
(\mathrm{Pa})\end{array}$ \\
\hline 1 & PVA & 1.15 & 1.67 \\
\hline 2 & PVA-Zr & 41.1 & 2.82 \\
\hline 3 & PVA-Zr-Cu (6 \%) & 43.5 & 2.76 \\
\hline 4 & PVA-Zr-Cu (8 \%) & 45.7 & 2.89 \\
\hline 5 & PVA-Zr-Cu (10 \%) & 49.2 & 3.13 \\
\hline 6 & PVA-Zr-Fe (6 \%) & 44.6 & 2.83 \\
\hline 7 & PVA-Zr-Fe (8 \%) & 61 & 2.91 \\
\hline 8 & PVA-Zr-Cu (4 \%)-Fe (4 \%) & 90.09 & 2.97 \\
\hline
\end{tabular}




\subsection{XRD Studies}

X-Ray diffraction (XRD) was carried out to study the crystal structures and the amorphous-crystalline phase vibrations. ${ }^{13}$ Figures $\mathbf{2 a}$ and $\mathbf{2 b}$ show the X-Ray diffractograms of the uncalcinated and calcinated specimens. From Figure 2 it is clear that three peaks are observed around $\sim 39^{\circ}, \sim 45^{\circ}, \sim 66^{\circ}$ and $\sim 79^{\circ}$, which denote the peaks for PVA, copper $(\mathrm{Cu})$, iron $(\mathrm{Fe})$ and zirconia $(\mathrm{Zr})$ respectively. From Figure $\mathbf{2}$ it is clear that the calcinated specimens show more intense peaks when compared with the uncalcinated samples, which were found in accordance with the findings of Ohtaki et al., ${ }^{14}$ and Abbas et al. ${ }^{15}$

From Figure 2a, the sample U1 shows the XRD diffractograms for PVA. Only two peaks are formed, which correspond to the amorphous and crystalline structures of PVA at $15.37^{\circ}$ and $22.42^{\circ}$ respectively. Thus, representing the crystalline structures of the carbon and hydrogen, while U2 shows the intensity peaks of PVA and $\mathrm{Zr}$ at $2 \theta=38.41^{\circ}$ and $78.51^{\circ}$, respectively. The intensity peaks of $\mathrm{Cu}$ rise with a rate corresponding to the percentage of $\mathrm{Cu} 6 \%, 8 \%$ and $10 \%$ added to the composite, where $\mathrm{Zr}$ and PVA are kept constant. Thus we can see from the composites U3, U4 and U5 that the intensity peak of $\mathrm{Zr}$ decreases, concerning the increase in the percentage of $\mathrm{Cu}$ and this eventually gives rise to the crystal peaks of $\mathrm{Zr}$ at $78.09^{\circ}, 78.10^{\circ}$, and $78.34^{\circ}$, respectively. The same aspect was found in accordance with the findings of Yeh et al. ${ }^{16}$ This phenomenon is attributed to the bonding of $\mathrm{Cu}$ atoms with $\mathrm{Zr}$.

From the diffractograms of U3, U4, U5 it is clear that the crystal intensity of $\mathrm{Cu}$ increases, which suppresses the intensity peak of the zirconia. The intense peak appeared due to the strong intermolecular attractions between the polymer chains and the intermolecular hydrogen bond. The diffractograms of U6 and U7 denote the peaks of $\mathrm{Fe}$ and $\mathrm{Cu}$ at $2 \theta=\sim 66$ and $\sim 79$, respectively. It is clear that the intensity peak of Fe increases in $\mathrm{U} 7$ due to the increase in the $w / \%$ of $\mathrm{Fe}$, while the $\mathrm{Zr}$ and PVA are kept constant at $8 \%$. The U8 diffractograms have three peaks at $2 \theta=44.92^{\circ}, 65.27^{\circ}$ and $78.42^{\circ}$, respectively, for copper, iron and zirconia. The peaks show that the crystallinity index of $\mathrm{Zr}$ rises when $\mathrm{Cu}$ and Fe are added at $4 \%$, respectively. This phenomenon occurs due to the high intermolecular bonding between the hydrogen and carbon atoms. ${ }^{15,17}$

Figure $\mathbf{2 b}$ shows the calcinated diffractograms of the same eight samples. The samples were calcinated at $500{ }^{\circ} \mathrm{C}$. The diffractograms observed are similar to Figure 2a due to the same composition, but the intensity peaks are much higher when compared to Figure 2a. This is because the monoclinic Fe and face-centred cubic $\mathrm{Cu}$ exhibit a strong intermolecular bond with orthogonal crystals of $\mathrm{Zr}$ when subjected to heat. ${ }^{16}$ This, in turn, plays a vital role in forming the strong crystal structures in the lattice plane. C8 shows a good crystal structure when compared to the other specimens. Another aspect is that the calcination of PVA in the case of $\mathrm{C} 2$ gives rise to a peak at 44.33 , as per the literature. ${ }^{18}$ The phenomenon was due to the dehydration during the calcination and altered the crystal structure in the presence of $\mathrm{Zr}$.
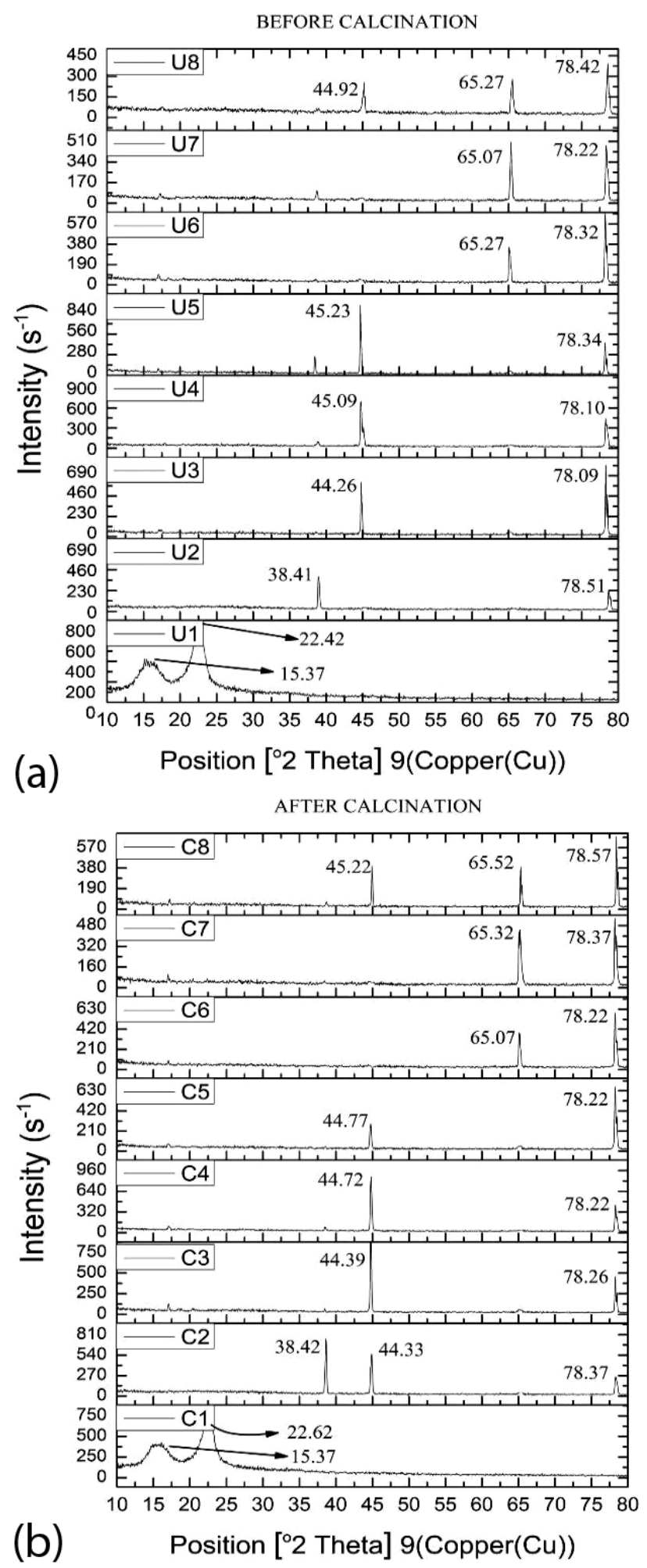

Figure 2: XRD diffractograms: a) uncalcinated nanofibres (U1-U8), b) calcinated nanofibres (C1-C8) 


\subsection{FTIR Studies}

The Fourier-transform infrared spectroscopic images of uncalcinated and calcinated specimens are shown in Figures $\mathbf{3 a}$ and $\mathbf{3 b}$.

From Figure 3a U1 shows the spectrogram peaks of PVA at $606 \mathrm{~cm}^{-1}, 850 \mathrm{~cm}^{-1}$, which were due to the stretching of the $\mathrm{C}-\mathrm{H}$ alkene. Later, a peak was seen at $1093 \mathrm{~cm}^{-1}$ due to the C-O alkoxy stretch. Further, it shows small bumps at $1242 \mathrm{~cm}^{-1}$, which are due to the $\mathrm{SP}^{3} \mathrm{C}-\mathrm{H}$ bending. And then a peak was seen at 1444 $\mathrm{cm}^{-1}$, due to the presence of the $\mathrm{C}=\mathrm{C}$ aromatic stretch. A small bump is observed at $2472 \mathrm{~cm}^{-1}$ due to $\mathrm{S}-\mathrm{H}$ thiol stretch. Some small peaks are observed at $2907 \mathrm{~cm}^{-1}$, due to the O-H carboxylic acid stretch. This is followed by a small bump at $3332 \mathrm{~cm}^{-1}$, due to the presence of the $2^{\circ}$ $\mathrm{N}-\mathrm{H}$ bond ${ }^{17}$.

U2 spectrograms from Figure 3a show the presence of $\mathrm{Zr}$ and PVA. The first peak was seen at $839 \mathrm{~cm}^{-1}$ and the second U-shaped peak was at $1083 \mathrm{~cm}^{-1}$, which denote the presence of the $\mathrm{C}-\mathrm{H}$ alkene and $\mathrm{C}-\mathrm{O}$ alkoxy stretch, respectively. The next concurrent peaks are seen at $1422 \mathrm{~cm}^{-1}$ and $1666 \mathrm{~cm}^{-1}$, which denote the presence of $\mathrm{N}-\mathrm{H}$ bending and $\mathrm{C} \equiv \mathrm{N}$ stretching. The next consequent peaks are observed at $2650 \mathrm{~cm}^{-1}, 2940 \mathrm{~cm}^{-1}$ and $3268 \mathrm{~cm}^{-1}$, which corresponds to $\mathrm{C}-\mathrm{H}$ aldehyde stretching, $\mathrm{O}-\mathrm{H}$ carboxylic acid stretch and the $2^{\circ} \mathrm{N}-\mathrm{H}$ stretch, respectively. The number of intense peaks is reduced, while new peaks such as $1666 \mathrm{~cm}^{-1}$ and $2059 \mathrm{~cm}^{-1}$ are formed, which denote the presence of $\mathrm{Zr} .{ }^{19}$

The next consecutive specimens U3, U4 and U5 show the spectrograms that corresponds to the presence of $\mathrm{Cu}$ that has been doped with PVA and $\mathrm{Zr}$ at a rate of $6 \%$, $8 \%$ and $10 \%$, respectively. From the spectrograms of
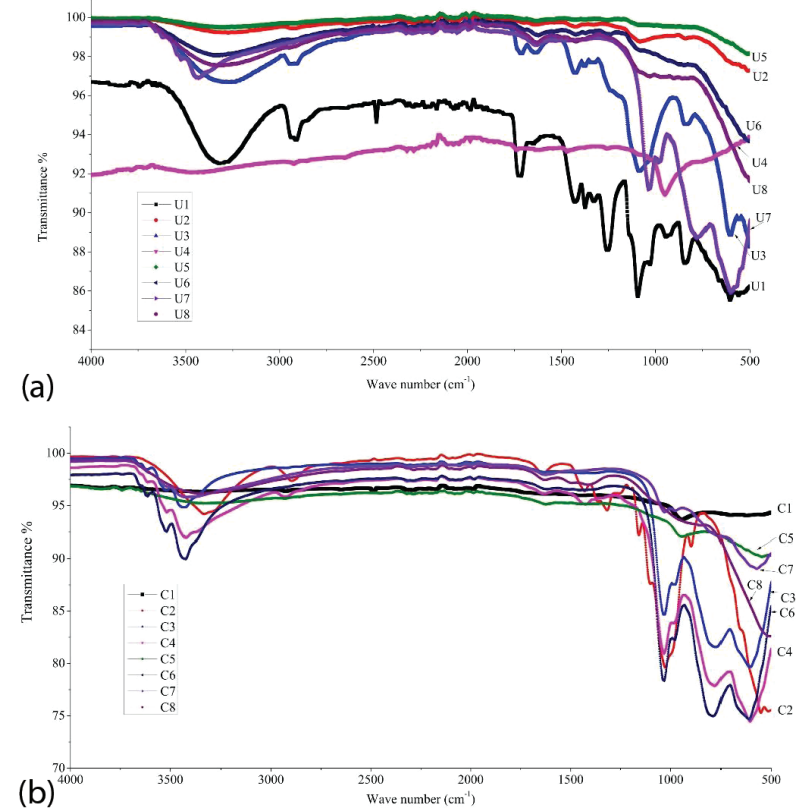

Figure 3: FTIR spectrum of: a) uncalcinated nanofibres, b) calcinated nanofibres
U3 and U5 the peaks observed are $627 \mathrm{~cm}^{-1}, 828 \mathrm{~cm}^{-1}$ and $945 \mathrm{~cm}^{-1}$, which correspond to the presence of the $\mathrm{C}-\mathrm{H}$ alkene stretch, ${ }^{20}$ while U7 does not show the presence of the $\mathrm{C}-\mathrm{H}$ alkene bond because $\mathrm{U} 7$ is doped with $10 \% \mathrm{CuSO}_{4}$. So the inter-lattice spaces are filled with sulphate and copper atoms, thus lowering the concentration of PVA. This results in a low penetration of IR rays. The next corresponding peak for U3 is found at $1072 \mathrm{~cm}^{-1}$, which shows the presence of the C-O alkoxy stretch. The next consecutive peaks of U3 are found at $1412 \mathrm{~cm}^{-1}, 1634 \mathrm{~cm}^{-1}, 1719 \mathrm{~cm}^{-1}, 2918 \mathrm{~cm}^{-1}$ and $3278 \mathrm{~cm}^{-1}$, which correspond to the presence of the $\mathrm{C}=\mathrm{C}$ aromatic stretch, $\mathrm{N}-\mathrm{H}$ bending, $\mathrm{C}=\mathrm{O}$ stretch, $\mathrm{O}-\mathrm{H}$ carboxylic acid and $2^{\circ} \mathrm{N}-\mathrm{H}$ stretching, respectively. The specimen U4 shows the intensity peak at $1465 \mathrm{~cm}^{-1}$, which is due to the $\mathrm{C}=\mathrm{C}$ aromatic stretch. The next peak is formed at $1740 \mathrm{~cm}^{-1}$ due to the vibration of $\mathrm{C}=\mathrm{O}$. The next consecutive peaks are found at $2059 \mathrm{~cm}^{-1}$ and 2302 $\mathrm{cm}^{-1}$, which correspond to $\mathrm{C} \equiv \mathrm{N}$. The next peak is formed at $2918 \mathrm{~cm}^{-1}$, which denotes the $\mathrm{O}-\mathrm{H}$ carboxylic acid, and the last peak is found at $3438 \mathrm{~cm}^{-1}$, which denotes the presence of the $\mathrm{O}-\mathrm{H}$ alcoholic stretch. From Figure 3a the U5 specimen shows the spectrogram recorded for $10 \%$ copper doped with $\mathrm{Zr}$ and PVA. There are lesser peaks in U5 when compared to U1, U2, U3 and U4 because the $10 \%$ copper doping prevents the IR from passing through the specimens, thus showing better quality.

The specimens U6 and U7 show spectrograms of Fe doped with $\mathrm{Zr}$ and PVA at the level of $8 \%$ and $10 \%$, respectively. From Figure 3a U6 shows intensity peaks at $1259 \mathrm{~cm}^{-1}$, which denotes the presence of C-O alkyl groups. The peak is formed at $1454 \mathrm{~cm}^{-1}$, representing the vibration of the $\mathrm{C}=\mathrm{C}$ aromatic presence. The next peak formed at $1632 \mathrm{~cm}^{-1}$, is due to the bending of the $\mathrm{N}-\mathrm{H}$ medium peak, and next one is observed at $2304 \mathrm{~cm}^{-1}$, which is attributed to the presence of $\mathrm{C} \equiv \mathrm{N}$ stretching. It is then followed by two consecutive peaks at $2492 \mathrm{~cm}^{-1}$ and $3343 \mathrm{~cm}^{-1}$, which were due to the molecular vibration and stretching of $\mathrm{S}-\mathrm{H}$ Thiol and $\mathrm{N}-\mathrm{H} 2^{\circ}$, respectively.

Figure 3a U8 shows the spectrograms of copper and iron-doped with $\mathrm{Zr}$ and PVA, only three peaks are observed at $1430 \mathrm{~cm}^{-1}, 1621 \mathrm{~cm}^{-1}$ and $3322 \mathrm{~cm}^{-1}$, which is due to the vibrational intensities due to the $\mathrm{C}=\mathrm{C}$ aromatic stretching, bending of $\mathrm{N}-\mathrm{H}$ bond and $2^{\circ} \mathrm{N}-\mathrm{H}$ stretching, respectively. So from the Figure 3a, we can observe that specimen U8 shows better results by preventing more transmittance of IR rays. ${ }^{21}$

Figure $\mathbf{3 b}$ shows the spectrogram of the calcinated eight samples, namely, C1, C2, C3, C4, C5, C6, C7 and C8. Sample C1 in Figure $\mathbf{3 b}$ shows intensity peaks for PVA at $943 \mathrm{~cm}^{-1}$, which were due to the bending of $\mathrm{sp}^{2}$ $\mathrm{C}-\mathrm{H}$. The next consecutive peaks are observed at 2053 $\mathrm{cm}^{-1}$ and $2485 \mathrm{~cm}^{-1}$, because of the stretching of $\mathrm{C} \equiv \mathrm{C}$ and $\mathrm{C} \equiv \mathrm{N}$, respectively. It is then followed by the stretching of S-H thiol at an intensity of $2652 \mathrm{~cm}^{-1}$ and then 
followed by small bumps at $2925 \mathrm{~cm}^{-1}$ and $3365 \mathrm{~cm}^{-1}$, which were due to the presence of $\mathrm{O}-\mathrm{H}$ carboxylic acid and stretching of $\mathrm{O}-\mathrm{H}$ alcohol, respectively. Specimen $\mathrm{C} 2$ shows intensity peaks that start at $1030 \mathrm{~cm}^{-1}$, which is due to the stretching of the $\mathrm{C}-\mathrm{O}$ alkoxy. The next peak is observed at $1316 \mathrm{~cm}^{-1}$, due to the stretching of $\mathrm{C}-\mathrm{O}$ (alkyl) and $\mathrm{C}=\mathrm{C}$, which indicates that the aromatic stretch was found at $1435 \mathrm{~cm}^{-1}$. The next intensity peak was due to the bending of $\mathrm{N}-\mathrm{H}$ at $1637 \mathrm{~cm}^{-1}$, which is then followed by the stretching of C-H aldehyde at 2898 $\mathrm{cm}^{-1}$. A small bump is observed at $3356 \mathrm{~cm}^{-1}$ due to $2^{\circ}$ $\mathrm{N}-\mathrm{H}$ stretching. Further, the $\mathrm{C} 3$ and the $\mathrm{C} 4$ specimens in Figure $3 \mathbf{b}$ show intensity peaks in the same manner. The first intensity peak is observed at $605 \mathrm{~cm}^{-1}$ and $604 \mathrm{~cm}^{-1}$, which is due to the bending of the $\mathrm{SP}^{2}$ aromatic alkene. The second consecutive intensity peaks are observed at $768 \mathrm{~cm}^{-1}$ and $782 \mathrm{~cm}^{-1}$, which are attributed to the bending of the $\mathrm{C}-\mathrm{H}$ alkene. The third, consecutive intensity peaks are observed at $1030 \mathrm{~cm}^{-1}$ and $1032 \mathrm{~cm}^{-1}$, which are due to $\mathrm{C}-\mathrm{O}$ alkoxy stretch. The last intensity peaks are observed at $3438 \mathrm{~cm}^{-1}$ and $3421 \mathrm{~cm}^{-1}$, which are attributed to the stretching of the $\mathrm{O}-\mathrm{H}$ alcohol. ${ }^{17,19}$

The C5 specimen shows only three intensity peaks when compared with the other specimens. The peaks are recorded at $943 \mathrm{~cm}^{-1}, 1632 \mathrm{~cm}^{-1}$, and $3355 \mathrm{~cm}^{-1}$, which are due to the bending of the $\mathrm{C}-\mathrm{H}$ alkene, bending of the $\mathrm{N}-\mathrm{H}$ and stretching of the $\mathrm{SP}^{2} \mathrm{C}-\mathrm{H}$ respectively.

Specimen C6 shows the spectrograms of Fe doped with $\mathrm{Zr}$ and PVA and also calcinated at $500{ }^{\circ} \mathrm{C}$. The peak is observed at $606 \mathrm{~cm}^{-1}$, which specifies the bending of the $\mathrm{SP}^{2}$ aromatic alkene. The second intensity peak is found at $788 \mathrm{~cm}^{-1}$, which is due to the bending of the $\mathrm{C}-\mathrm{H}$ alkene. The third intensity peak is observed at $1038 \mathrm{~cm}^{-1}$, which is due to the alkoxy stretching of C-O. The fourth intensity peak is observed at $3439 \mathrm{~cm}^{-1}$ and $3522 \mathrm{~cm}^{-1}$, which is attributed to the stretching of the $\mathrm{O}-\mathrm{H}$ alcohol. The specimen $\mathrm{C} 7$ shows the first intensity peak at $1022 \mathrm{~cm}^{-1}$, which is due to the alkoxy stretching of $\mathrm{C}-\mathrm{O}$. The second intensity peak is observed at $1621 \mathrm{~cm}^{-1}$, which is due to the bending of N-H. The last intensity peak is recorded at $3414 \mathrm{~cm}^{-1}$, which is due to the stretching of the O-H alcohol.

Specimen C8 shows the spectrograms of the calcinated specimen $\mathrm{Fe}$ and $\mathrm{Cu}$ doped with PVA and Zr. Only three intensity peaks are formed. The first peak was at $1429 \mathrm{~cm}^{-1}$ due to the bending of SP ${ }^{3} \mathrm{C}-\mathrm{H}$. The second peak is due to the aromatic stretching of $\mathrm{C}=\mathrm{C}$ at $1631 \mathrm{~cm}^{-1}$. The last peak was observed at $3349 \mathrm{~cm}^{-1}$, due to the stretching of the alcohol O-H. ${ }^{21}$

In Figures 3a and $\mathbf{3 b}$ the intensity peaks are reduced because calcination disintegrates the PVA molecules. This leads to better adhesion of the $\mathrm{Fe}$ and $\mathrm{Cu}$ with the $\mathrm{Zr}$, providing good structural stability. The phenomenon is proved by less transmittance of the IR rays by the calcinated specimens.

\subsection{TGA studies}

The thermal stability of the developed nanofibres was found by measuring the weight loss related to temperature using TGA. The TGA curves for the uncalcinated and calcinated nanofibres are given in Figure $\mathbf{4 a}$ and $\mathbf{4 b}$.

When the U1 nanofibres are subjected to heat, a drastic weight loss occurred, as shown in Figure 4a, mainly at three stages. The first stage is from $60{ }^{\circ} \mathrm{C}$ to $155^{\circ} \mathrm{C}$, which is due to the weight loss due to moisture content. Followed by $155{ }^{\circ} \mathrm{C}$ to $200{ }^{\circ} \mathrm{C}$, which is mainly due to the dehydration process, which is the loss of internal water molecules. Then from $230{ }^{\circ} \mathrm{C}$ to $445{ }^{\circ} \mathrm{C}$, this is mainly due to the breakage and evaporation of the polymer molecule chain. After $445{ }^{\circ} \mathrm{C}$ it may be due to the semi-crystalline nature of PVA. While in case of $\mathrm{C} 1$, as shown in Figure $\mathbf{4 b}$, there is a slight deviation in the temperature range, since it is calcinated $\left(150^{\circ} \mathrm{C}\right)$. So it showed dehydration of the internal water molecule structure until $230{ }^{\circ} \mathrm{C}$, followed by the polymer chain break-
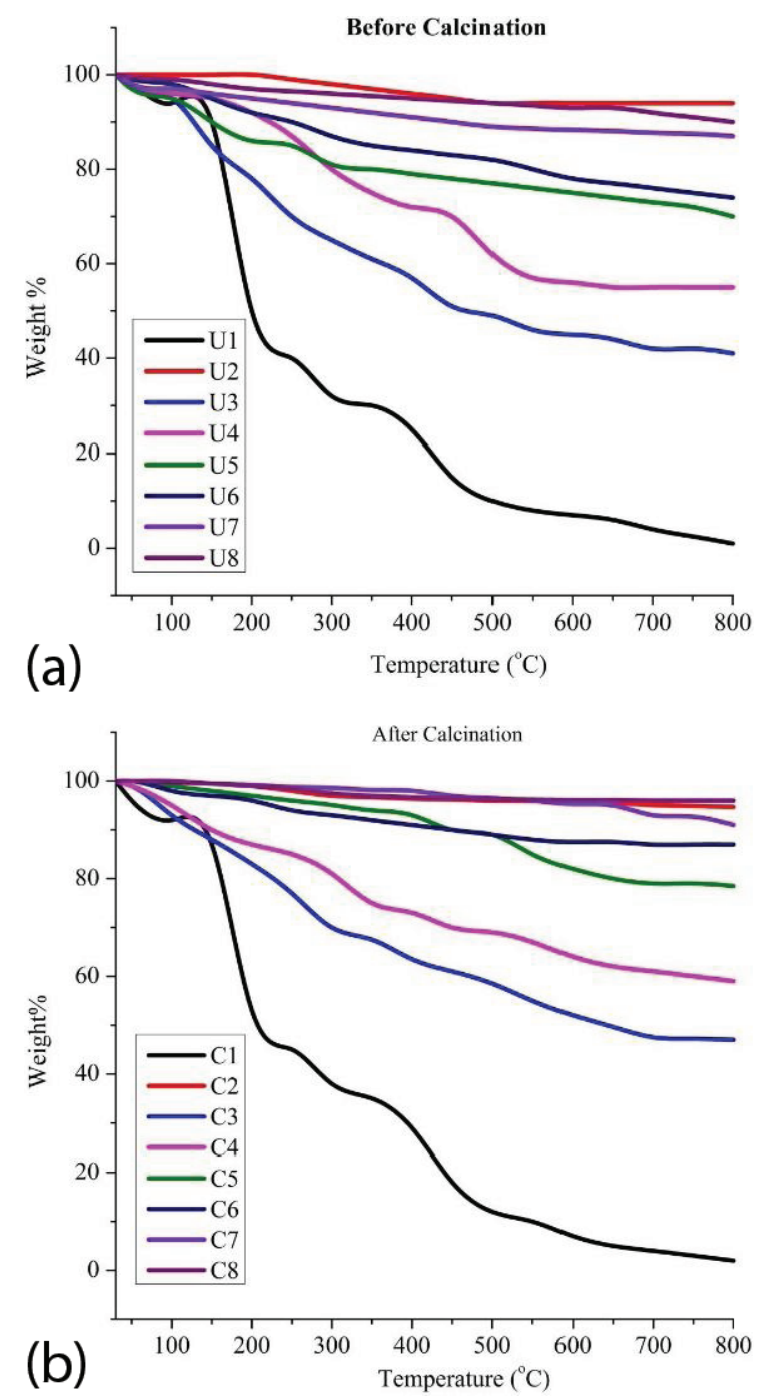

Figure 4: TGA curves of: a) uncalcinated nanofibres, b) calcinated nanofibres 
age and evaporation until $440{ }^{\circ} \mathrm{C}$. The weight loss of $\mathrm{C} 1$ is $98 \%$, while it is $99 \%$ for $\mathrm{U} 1$.

In the case of U2, it had very little weight loss, which is mainly due to the PVA and internal water molecules from adjacent $\mathrm{OH}$ groups. This is in accordance with the findings of Sigwadi et al. ${ }^{22}$ While in the case of the C2 composites the weight loss is much less when compared to $\mathrm{U} 2$, due to the removal of water molecules during
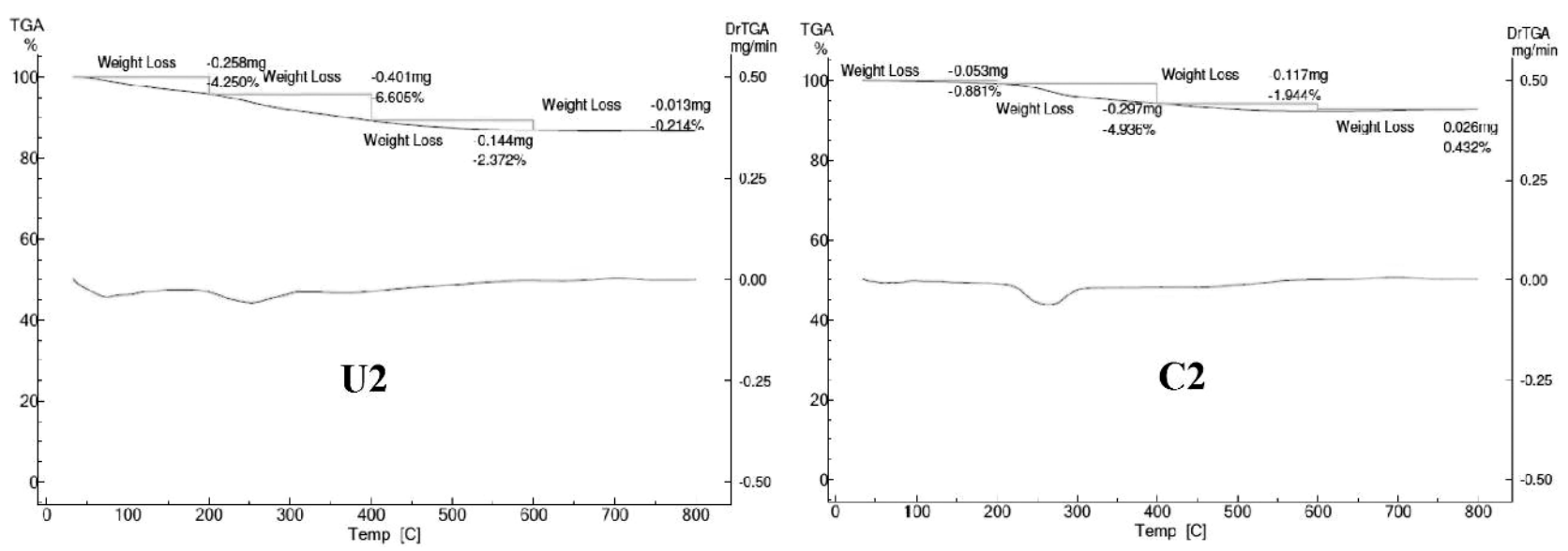

Figure 5: Typical TG-DTA curves of: a) U2, b) C2
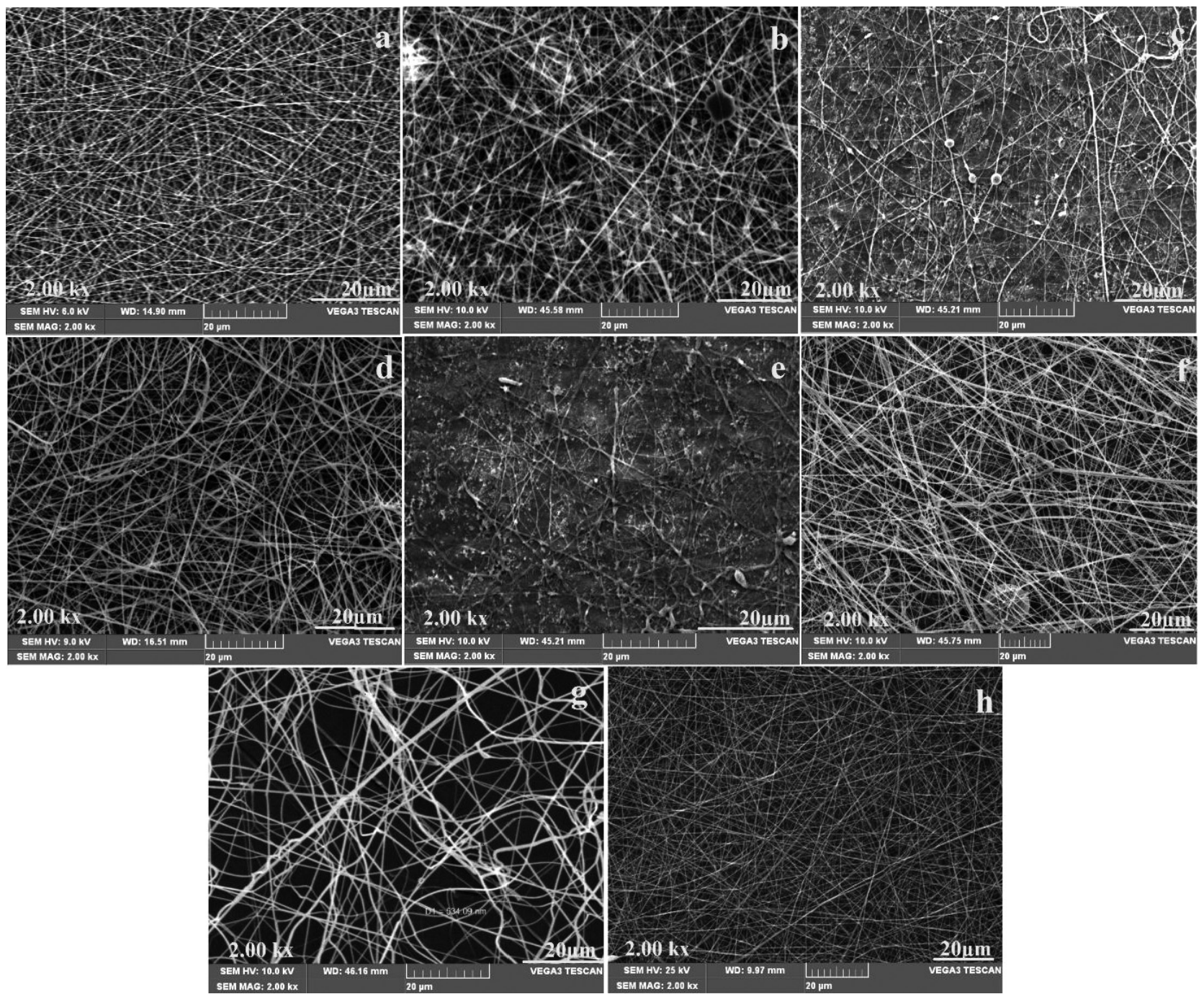

Figure 6: SEM images of uncalcinated fibres: a) U1, b) U2, c) U3, d) U4, e) U5, f) U6, g) U7, h) U8 
calcination. To study in detail the weight loss of Zr-PVA, the DTA curves were analysed as shown in Figure 5a and $\mathbf{5 b}$ for the $\mathrm{U} 2$ and $\mathrm{C} 2$ composites. The U2 composites showed two endothermic peaks, which are due to the moisture dehydration and then the second one is due to the polymer chain breakage. The $\mathrm{C} 2$ composites showed that the only one which is mainly due to the internal polymer chain breakage is in accordance with the findings of Pessoa et al. ${ }^{23}$ The weight losses of the $\mathrm{U} 2$ and $\mathrm{C} 2$ nanofibres are $5 \%$ and $6 \%$. The TGA curves for the doped fibres showed different trends. The dopant-based nanofibres showed broader curves due to the presence of dopants, which interrupt the heat through it. The copper-dopant-based zirconia nanofibres showed better thermal resistance, while the iron-dopant-based zirconia nanofibres showed more stability. This is mainly due to the crystallisation structure. It is very clear from the $\mathrm{C} 8$ composites as shown in Figure $\mathbf{4 b}$, where the weight loss is much less when compared to the other fibres, which are mainly due to the homogenous distri- bution and optimal percentage of copper and iron. Also, upon calcination, the materials are stabilised, as shown in the XRD. This nature plays a crucial role in withstanding the thermal resistance behaviour of the fibres. The weight loss of $\mathrm{C} 8$ is much less, i.e., $3.7 \%$, only when compared to the other fibres. It is now clear that the calcinated, dopant-based nanofibres are the potential materials for thermal stability, which is also due to the conductive and higher melting temperatures of the dopants.

\subsection{Morphological studies of the developed nanofibres}

SEM studies were used to study the morphology of the developed nanofibres. The SEM images of the uncalcinated nanofibres are given in Figure $\mathbf{6 a}$ to $\mathbf{6 h}$ in which the fibre diameter is greater than the calcinated one. The prime reasons for such behaviour are mainly due to the presence of PVA in the composition. Generally, the calcination of fibres removes the PVA from its composition, which leads to the reduction in the diameter. It is stated
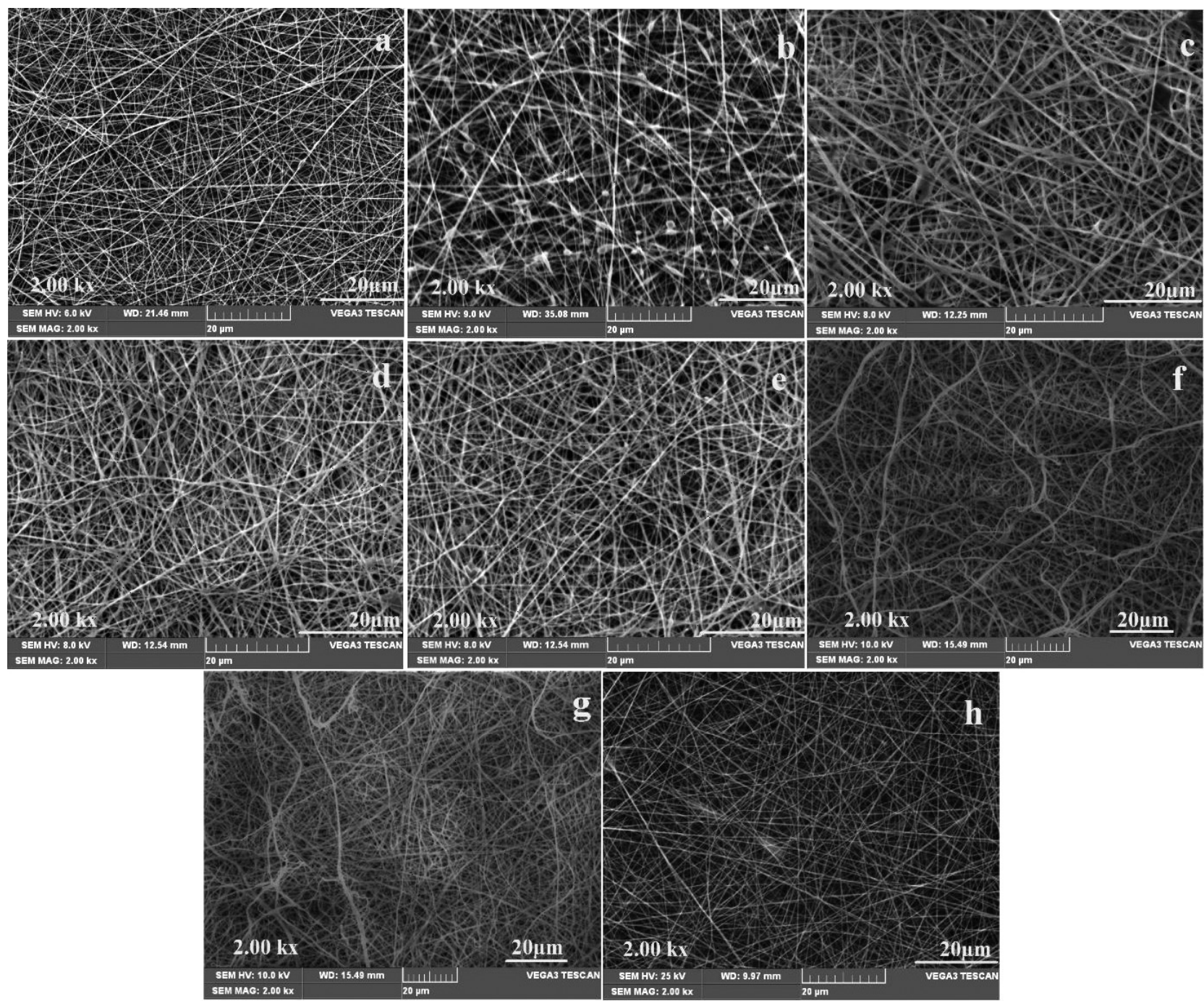

Figure 7: SEM images of calcinated fibres: a) C1, b) C2, c) $\mathrm{C} 3$, d) $\mathrm{C} 4$, e) $\mathrm{C} 5, \mathrm{f}) \mathrm{C} 6, \mathrm{~g}) \mathrm{C} 7, \mathrm{~h}) \mathrm{C} 8$ 


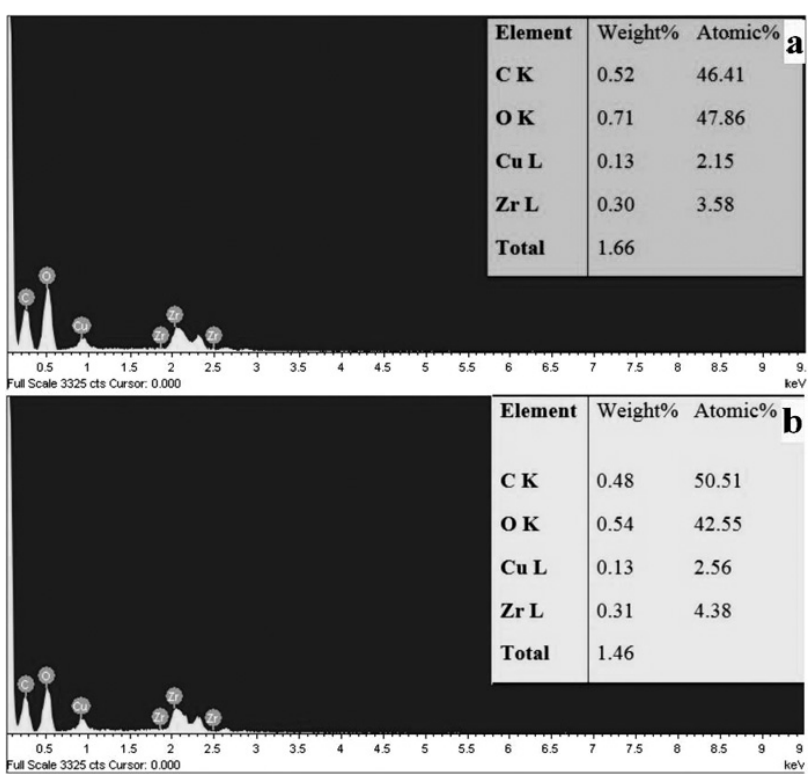

Figure 8: EDX spectrum of: a) U3 Sample, b) C3 Sample

in the literature that PVA provides a good surface finish and smoothness to the structure, but upon calcination, this nature is changed, which is visible from Figures $6 \mathbf{f}$ and 7f. It is also stated in the literature that PVA plays the role of the template during spinning. If it is removed, then there will be an abrupt change in the diameter. The degradation of PVA is also justified from the SEM images (Figures 6a and 7a in which there is a drastic change in diameter of the fibres. To justify the removal of the smoothness, the surface roughness was measured, which is shown as $112 \mathrm{~nm}$ for U6 composite, while it is $145 \mathrm{~nm}$ for the C6 composite. This is in accordance with the findings of Dharmaraj et al. ${ }^{24}$ in which the zirconium oxide nanofibres upon calcination gave a higher surface roughness. This is because of the crystallisation of zirconia at elevated temperature though the temperature of calcination is not so high in the present study, but there is a slight modification in the structure, which could be confirmed from the XRD studies in Figure $\mathbf{2 b}$. It is said in the literature that a change in the diameter is not only due to the precursor, but also due to the shrinkage of the fibres due to structural changes. ${ }^{25}$

The same is also confirmed using the EDX, as shown in Figure 8b, in which there is an increase in the $\mathrm{Cu}$ and $\mathrm{Zr} \%$ than in Figure 8a. Another possible reason could also be due to the presence of metal dopants, which enhances the conductive nature and allows the heat to percolate to it, leading to such a nature. Figures $\mathbf{9 a}$ and $\mathbf{9 b}$ show the frequency distribution of the diameter in uncalcinated and calcinated copper (6\%) doped zirconia nanofibres, in which the average diameter is less for the calcinated (C3) sample. It is a postulate that the doped nanofibres have a larger diameter than the undoped one, which is also found in our study, where the average diameter of $\mathrm{C} 3$ is 1.71 times higher than $\mathrm{C} 2$. This is a
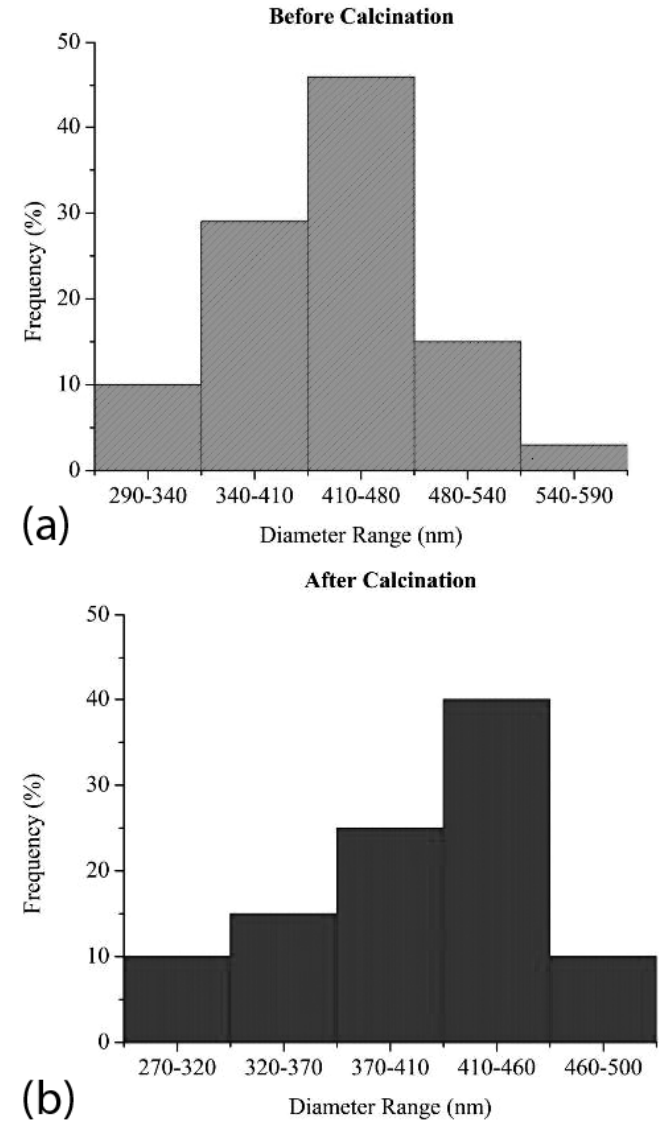

Figure 9: Frequency of diameter distribution in U3 and C3 nanofibres

concept as per the findings of Uslu et al. ${ }^{3}$ in their study on boron-doped alumina-stabilised zirconia nanofibres produced by electrospinning. ${ }^{3}$ The dopant-based zirconia nanofibres showed good round and even shaped fibres with an appreciable diameter, as per the literature. The undoped nanofibres showed a needle-like structure with beads, as visualised in the SEM images in Figures $6 \mathbf{b}$ and $\mathbf{7 b}$, which is mainly due to the poor viscosity, which was due to the rough surface and some defects. ${ }^{26}$

Similarly, in case of Figure 6e, which possess high viscosity, it leads to form more net-shaped structures that interrupt the homogenous distribution of fibres, forming a good structure. The good diameter properties are shown in Figures $\mathbf{6 h}$ and $\mathbf{7 h}$, which is mainly due to the conductance of the fibres. Better conductance, which will be helpful for the dispending of good diameter based fibres without the formation of any beads and defects, is in accordance with the studies of Cui et al. ${ }^{26}$ It is also stated that the conductance is based on the dopants available ${ }^{27}$ as well as on its mechanical behaviour.

The mean diameter on the nanometre scale is given in Table 3. This is in line with the discussion above. The EDX of the other samples also showed a similar trend concerning their composition, so only the U3 and C3 fibres are alone discussed. This diameter change and surface roughness will be very helpful for the application aspects of the developed fibres. 
Table 3: Mean diameter of the uncalcinated and calcinated nanofibres on the nanoscale

\begin{tabular}{|c|c|c|}
\hline Sample & $\begin{array}{c}\text { Uncalcinated } \\
(\mathrm{U}) / \mathrm{nm}\end{array}$ & $\begin{array}{c}\text { Calcinated } \\
(\mathrm{C}) / \mathrm{nm}\end{array}$ \\
\hline 1 & 243 & 225 \\
\hline 2 & 273 & 259 \\
\hline 3 & 441 & 385 \\
\hline 4 & 503 & 411 \\
\hline 5 & 609 & 512 \\
\hline 6 & 570 & 526 \\
\hline 7 & 758 & 628 \\
\hline 8 & 856 & 710 \\
\hline
\end{tabular}

\section{CONCLUSIONS}

The doped and undoped zirconia nanofibres were synthesised using the electrospinning technique, further calcinated at elevated temperatures and characterised. Based on the test results the following conclusions were drawn:

- Zirconia doped with copper and iron showed two times higher conductance than the other dopant-based samples.

- XRD of the calcinated dopant-based nanofibres showed good crystalline peaks and structures since monoclinic $\mathrm{Fe}$ and face-centred cubic $\mathrm{Cu}$ exhibited a strong intermolecular bond with orthogonal crystals of $\mathrm{Zr}$ upon calcination.

- Calcinated zirconia nanofibres doped with metals showed good bond stretching in the FTIR spectra and the calcinated zirconia nanofibres doped with copper and iron (hybrid) showed a better structural stability than the other composites.

- Calcinated zirconia nanofibres doped with copper and iron showed less weight loss $(3.7 \%)$, which proved its better thermal stability.

- SEM studies showed that the diameter characteristics of the calcinated nanofibres are less compared to the uncalcinated samples, i.e., 0.83 times lower than the uncalcinated sample in the case of zirconia doped with iron and copper. It also showed good diameter characteristics. EDX showed there was reduced levels of $\mathrm{C}$ and $\mathrm{O} \%$ due to the removal of the PVA from the surface.

- Thus, from the above results, it is clear that calcinated zirconia nanofibres doped with copper and iron are the positive solution for better conductance. The future work is to develop a polymer composite using dopant-based zirconia nanofibres and to characterise them.

\section{REFERENCES}

${ }^{1}$ R. Vasita, D. Katti, Nanofibers and their applications in tissue engineering, International Journal of Nanomedicine, 1 (2006) 1, 15-30

${ }^{2}$ R. Sarbatly, Z. Kamin, D. Krishnaiah, A review of polymer nanofibres by electrospinning and their application in oil-water separation for cleaning up marine oil spills, Marine Pollution Bulletin, 106 (2016), 8-16, doi:10.1016/j.marpolbul.2016.03.037

${ }^{3}$ I. Uslu, T. Tunç, S. Keskin, M. K. Öztürk, Synthesis and characterization of boron doped alumina stabilized zirconia fibers, Fibers and Polymers, 12 (2011) 3, 303-309, doi:10.1007/s12221011-0303-1

${ }^{4}$ A. Pavelková, P. Kucharczyk, V. Sedlařík, Electrospinning of biodegradable polyester urethane: Effect of polymer-solution conductivity, Mater. Tehnol., 51 (2017) 2, 195-197, doi:10.17222/mit.2015.139

${ }^{5}$ C. R. Martin, Template synthesis of electronically conductive polymer nanostructures, Accounts of Chemical Research, 28 (1995) 2, 61-68, doi:10.1021/ar00050a002

${ }^{6}$ C. R. Hammond, D. R. Lide (editor), The Elements, CRC Handbook of Chemistry and Physics. New York: CRC Press, 4 (2005) 36

${ }^{7}$ N. Jing, M. Wang, J. Kameoka, Fabrication of ultrathin $\mathrm{ZrO}<$ sub. 2 nanofibers by electrospinning, Journal of Photopolymer Science and Technology, 18 (2005) 4, 503-506, doi:10.2494/photopolymer. 18.503

${ }^{8}$ H. Ahmad, K. Thambiratnam, M. C. Paul, A. Z. Zulkifli, Z. A. Ghani, S. W. Harun, Fabrication and application of zirconia-erbium doped fibers, Optical materials express, 2 (2012) 12, 1690-1701, doi:10.1364/OME.2.001690

${ }^{9}$ T. Tunc, I. Uslu, Fabrication and characterization of boron doped yttria-stabilized zirconia nanofibers, Polymer Engineering \& Science, 53 (2013) 5, 963-969, doi:10.1002/pen.23345

${ }^{10}$ T. Pirzada, S. A. Arvidson, C. D. Saquing, S. S. Shah, S. A. Khan, Hybrid silica-PVA nanofibers via sol-gel electrospinning, Langmuir, (2012) 2813, 5834-5844, doi:10.1021/la300049j

${ }^{11}$ R. Seeram, L. Teik-cheng, F. Kazutoshi, An introduction to electrospinning and nanofibers, World Scientific: Singapore, (2005)

${ }^{12}$ S. Keskin, I. Uslu, T. Tunç, M. Öztürk, A. Aytimur, Preparation and characterization of neodymia doped PVA/Zr-Ce oxide nanocrystalline composites via electrospinning technique, Materials and Manufacturing Processes, 26 (2011) 11, 1346-1351, doi:10.1080/ 10426914.2011.551954

${ }^{13}$ J. Emsley, Nature's building blocks: an AZ guide to the elements, Oxford University Press, (2001), 506-510

${ }^{14} \mathrm{H}$. Ohtaki, T. Yamaguchi, M. Maeda, X-ray diffraction studies of the structures of hydrated divalent transition-metal ions in aqueous solution, Bulletin of the Chemical Society of Japan, 49 (1976) 3, 701-708, doi:10.1246/bcsj.49.701

${ }^{15}$ M. R. Abbas, A. M. Noor, S. R. Rajoo, N. O. Ahmad, U. M. Basheer, M. H. M. Sah, Thermal conductivity and specific heat capacity of different compositions of yttria stabilized zirconia-nickel mixtures, Advanced Materials Research, 1119 (2015), 783-788, doi:10.4028/www.scientific.net/AMR.1119.783

${ }^{16}$ J. W. Yeh, S. Y. Chang, Y. D. Hong, S. K. Chen, S. J. Lin, Anomalous decrease in $\mathrm{X}$-ray diffraction intensities of $\mathrm{Cu}-\mathrm{Ni}$-AlCo-Cr-F-Si alloy systems with multi-principal elements, Materials chemistry and physics, 103 (2007) 1, 41-46, doi:10.1016/ j.matchemphys.2007.01.003

${ }^{17}$ H. S. Mansur, R. L. Oréfice, A. A. Mansur, Characterization of poly (vinyl alcohol)/poly (ethylene glycol) hydrogels and PVA-derived hybrids by small-angle X-ray scattering and FTIR spectroscopy, Polymer, 45 (2004) 21, 7193-7202, doi:10.1016/j.polymer.2004. 08.036

${ }^{18}$ R. Ricciardi, F. Auriemma, C. De Rosa, F. Lauprêtre, X-ray diffraction analysis of poly (vinyl alcohol) hydrogels, obtained by freezing and thawing techniques. Macromolecules, 37 (2004) 5, 1921-1927, doi: $10.1021 / \mathrm{ma0} 035663 \mathrm{q}$

${ }^{19}$ E. E. Platero, M. P. Mentruit, C. O. Areán, A. Zecchina, FTIR studies on the acidity of sulfated zirconia prepared by thermolysis of zirconium sulfate, Journal of Catalysis, 162 (1996) 2, 268-276, doi:10.1006/jcat.1996.0284

${ }^{20}$ C. Schild, A. Wokaun, A. Baiker, On the mechanism of $\mathrm{CO}$ and $\mathrm{CO}_{2}$ hydrogenation reactions on zirconia-supported catalysts: a diffuse reflectance FTIR study: Part II. Surface species on copper/zirconia 
catalysts: implications for methanoi synthesis selectivity, Journal of molecular catalysis, 63 (1990) 2, 243-254, doi:10.1016/03045102(90)85147-A

${ }^{21}$ M. Razavet, S. J. Borg, S. J. George, S. P. Best, S. A. Fairhurst, C. J. Pickett, Transient FTIR spectroelectrochemical and stopped-flow detection of a mixed valence $\{\mathrm{Fe}$ (i)-Fe (ii) $\}$ bridging carbonyl intermediate with structural elements and spectroscopic characteristics of the di-iron sub-site of all-iron hydrogenase, Chemical Communications, 7 (2002), 700-701, doi:10.1039/B111613B

${ }^{22}$ R. A. Sigwadi, S. E. Mavundla, N. Moloto, T. Mokrani, Synthesis of zirconia-based solid acid nanoparticles for fuel cell application, Journal of Energy in Southern Africa, 27 (2016) 2, 60-67

${ }^{23}$ R. C. Pessoa, M. Cerqueira, R. S. Nasar, I. V. P. Yoshida, Synthesis of stabilized zirconia without dopants. Cerâmica, 54 (2008) 330, 253-258, doi:10.1590/S0366-69132008000200016
${ }^{24}$ N. Dharmaraj, C. H. Kim, H. Y. Kim, Synthesis and characterisation of zirconium oxide nanofibers by electrospinning, Synthesis and Reactivity in Inorganic, Metal-Organic and Nano-Metal Chemistry, 36 (2006) 1, 29-32, doi:10.1080/15533170500471 391

${ }^{25} \mathrm{H}$. Wu, P. Wei, Preparation of zinc oxide nanofibers by electrospinning, Journal of the American Ceramic Society, 89 (2006) 2, 699-701, doi:10.1111/j.1551-2916.2005.00735.x

${ }^{26}$ X. M. Cui, Y. S. Nam, J. Y. Lee, W. H. Park, Fabrication of zirconium carbide $(\mathrm{ZrC})$ ultra-thin fibers by electrospinning, Materials Letters, 62 (2008) 12-13, 1961-1964, doi:10.1016/j.matlet.2007. 10.051

${ }^{27}$ R. N. P. Choudhary, H. R. Rukmini, M. R. Rangaraju, Synthesis and characterization of sol-gel-prepared alkali-ion-doped PLZT ceramics, Proceedings of Smart Materials, Structures, and Systems 5062 (2003), 139-146, doi:10.1117/12.514847 